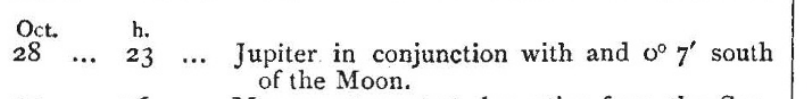

31 ... I6 ... Mercury at greatest elongation from the Sun, $19^{\circ}$ west.

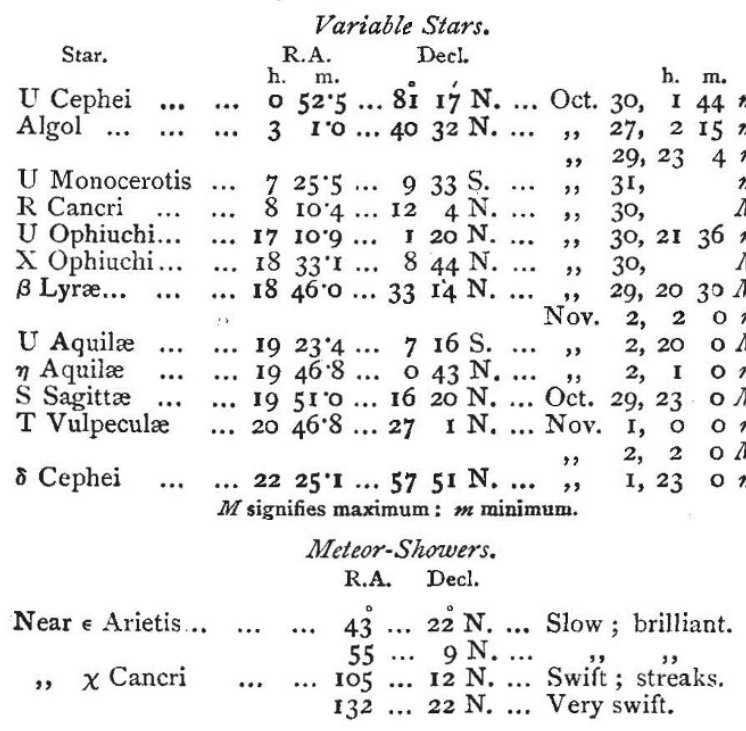

\section{THE GEOGRAPHICAL PAPERS AT THE BRITISH ASSOCIATION.}

SCIENTIFIC geography did not form a prominent feature in the Geographical Section at Newcastle. As was right and proper in so important an industrial centre, it was evidently intended to devote special attention to commercial geography. The success was only partial. It will have been seen that the President, Sir Francis De Winton, devoted a considerable part of his address to pointing out some of the important practical applications which may be made of geographical knowledge. Again, one of the ablest and most instructive papers read in the Section was by Dr. Hugh Robert Mill, on the Physical Basis of Commercial Geography. A necessary preliminary, Dr. Mill pointed out, to the study of commercial geography is a full acquaintance with topography, especially with the names and positions of all commercial towns. A necessary accompaniment to the study of commercial geography is a knowledge of the ever-varying relations between regions of supply and demand, the incidence of tariffs, and the political and social conditions of countries. The physical basis of commercial geography, which underlies and gives unity to the whole subject, is a knowledge of the resources of the earth as regards the various existing forms of matter and modes of energy, the best means of separating, combining, and modifying these so as to produce commodities, and the way in which commodities can be best transported. Commerce being the artificial redistribution of the matter and energy of the world, a knowledge of the general properties and the unchangeable laws of matter and energy should take a chief place in the training of cormmercial men. A general acquaintance with this practical science, which may be termed applied phy. siography, or practical earth knowledge, ought to be possessed by all merchants, and a special branch should be familiar to each. Amongst the advantages which would thus be gained are :-(1) The merchant would understand the principles of the production and manufacture of his goods. (2) He would know in many cases, without aimless and extravagant experiments, where it is possible to produce any special commodity in great abundance. (3) $\mathrm{He}$ could, to a great extent, anticipate the frequent changes in staple commodities by knowing what other commodities it is possible to produce in the regions now yielding the staple only. (4) He would understand the best and shortest routes between trade centres. Illustrations and arguments showing the importance of these statements were given in Dr. Mill's paper, and a large map of the commercial development of the world was shown. Dr. Mill has thus done something to give definite shape to a conception of commercial gecgraphy. The fact is, applied geography in general, like applied chemistry or applied physics, implies a sound knowledge of the subject as a science. If the facts and principles of the subject are thoroughly known, their application need not be difficult. This application cannot be said to have been very successful in Section E. The evident object in view was to exemplify by special examples the principles laid down in the President's address and in Dr. Mill's paper. Thus we had a series of papers on what purported to be the commercial geography of a number of countries or regions. The geography, however, in most cases was conspicuous by its absence. The papers were certainly most useful in their way, and doubtless would be of some commercial value. Thus Colonel Mark Bell's paper on the great Central Asian trade route from Peking to Kulja and Semrechensk, and to Yarkand and India, abounded with original information collected by an acute observer, and it is hoped will be published in full by the Royal Geographical Society. But the minute details dwelt upon by the author were quite unsuited to an audience. Mr. R. S. Gundry's review of industrial and commercial progress in China was admirable in its way, and the views enunciated by the author original and suggestive. The conclusion come to was that a more widespread desire for progress and radical financial reform will be required before China is likely to rival Japan in the completeness of its transformation.

There was as usual a considerable number of African papers, some of them really good even from the geographical standpoint. Governor Moloney gave much useful information on the Yoruba country and its various tribes, his paper, however, being mainly occupied with suggestions as to its industrial development. The same may be said of Captain Lugard's paper on Nyassaland, and Mr. Rankin's on the Zambesi. The Rev. R. P. Ashe's paper on Buganda contained little not already published in his recent work; it dealt mainly with the natives, their political organizations, their religion, manners, and customs. Captain E. C. Hore's paper on Lake Tanganyika was one of the best in the Section. The author, who has lived ten years on the lake, described its geographical position, as occupying the central depression of the heights of Africa, from the surrounding barrier of which descend the furthest sources of the great rivers; referred to its outlet, the Lukuga, and remarked upon certain earthquake phenomena, and the aspect of the depression and of the bed of the lake. He gave a general description of the lake, with the results of meteorological observations and notices of scenery, and aspects of the lake under various changes of weather. He described the natives living on the shores of the lake and within the central depression, as representing all the great A frican families, and gave some account of their arts and industries, and of the produce of the lake region. He sketched the African routes and lines of communication as converging towards or crossing the lake, and the present available approaches to the lake from the east coast. He then referred to the position of the lake amongst and in relation to present claims and operations in Central Africa, pointing out what European enterprise has already achieved on the lake.

An excellent paper in physical geography was that of $\mathrm{Mr}$. Flinders Petrie on Wind-Action in Egypt, the results of his own recent olservations in the Nile Delta. He stated that the underlying motions of the Delta are depression on the coast and upheaval at Ismailiyeh. Above these movements great changes have been made by wind-action; in some sites at least 8 feet of ground has been removed and deposited in the water. This has partly caused the great retreat of the Red Sea head, and tends to form the characteristic swamps of this district. Formerly the Delta was a desert tract, with valleys inundated by the Nile. Before historic times the Nile valley was deep in water, partly estuarine, partly fluvial, and great rainfall then took place. That this was in the human age is shown by the position of worked flints.

Mr. Batalha Reis, in his paper on recent Portuguese explorations in Africa, put in a claim for exploring activity on behalf of Portugal which it would be difficult to substantiate. Mr. E. G. Ravenstein made some important corrections in the course of the Upper Nile as laid down in recent German maps.

Mr. Basil Thomson's paper, on his recent expedition to the D'Entrecasteaux and Louisiade Islands, was the same as that given some time ago to the Royal Geographical Society, and reported in NATURE. Dr. Carl Lumholtz's paper, on the present and future of Queensland, was highly interesting and useful from a colonial point of view. He, moreover, gave some of the. 
results of his own observations during the time he lived with the natives as one of themselves. He found them to be undoubted cannibals, and predicts their early extinction.

One of the most original and scientific papers in the Section was that of Dr. Guppy on the south coast of West Java. The author dealt with a part of Java which has not been much described. It is one of the least familiar portions of this large island, a circumstance due partly to its paucity of anchorages and to the difficulty in landing; partly to its having been allowed to become in some places a kind of menagerie ; and partly, also, to the fact that it lies remote from the chief seats of government. Now that the Netherlands Indian Government are rapidly carrying out their systematic survey of the Preanger Residency, it will not be long before the south coast of West Java will be much better known than it is at present; and the recent extension of the central railway to Garoet and Tjirajap will do much to effect this end. The author's tracks over West Java would make a chequered pattern on a map; but he has thought it best not to refer to localities already well known-localities which are now yearly visited by hundreds of visitors. Taking the central railway as his base, he performed nearly all the distance on foot, walking about 560 miles in all. In the paper he endeavoured to give a general idea of this south coast alone. The huge volcanic cones were landmarks to him, and nothing more; they had been well described by Junker and others, so he resisted the temptation of climbing them, and reserved his main efforts for the examination of the little-described and remote south consts of the Preanger and Bantam Residencies. The object he had in view was to ascertain what physical evidence there was for the belief that the west end of Java was originally united with Sumatra. In this paper the author showed that all the evidence on the Java side of the Sunda Sirait points to the opposite con clusion. Zoological evidence cannot be held sufficient to establish the previous connection between two islands without the physica evidence of such a change. The problem, as usually stated, seems to begin at the wrong end of the matter. Given the present distribution of plants and animals, it is then attempted to explain the previous arrangement of the land, and this is done too often without appealing to the physical evidence at all. In tracing geographical changes in the past, it would seem more reasonable to adopt an opposite method; but in the great majority of cases affecting the distribution of animals, it would be wiser in the first place to assume the status quo, and fall back when that fails on the physical evidence of the presumed changes.

As was rightly pointed out by Mr. H. J. Mackinder, Dr. Guppy's apparent contempt of the argument from zoological distribution is to be deplored. Hitherto it has been regarded, and rightly so, by the ablest biologists and geographers, as one of the surest and most valuable keys to past geographical conditions; and it will require much more powerful arguments than Dr. Guppy was able to adduce in his paper to cast it aside.

In a paper on recent explorations in Peru and Bolivia, Mr. $\mathrm{H}$ Guillaume described the efforts which have been made by Peruvian and Bolivian explorers and traders to open up the rivers and the dense forest country lying between them. Colonel Labre since 1872 has been endeavouring to open communication from the Purus to the Beni. He explored the River Itury and its affluents several times, as to the character and navigability of which he has contributed much new information. Padre Nicolas Armentia explored the Madre de Dios in 1885 , and resided for some time in the country of the Araonas Indians. From its mouth for 280 miles the river receives no important tributary the Padre believes it has a navigable course of 400 miles for steamers. Mr. Guillaume described in detail the gold-bearing region at the source of the Madre de Dios. He then referred to the expiorations of Senor Carlos Fry on the Ucayli and its tributary, the Urubamba.

Mr. Theodore Bent's paper, on his recent visit to the Bahrein Islands in the Persian Gulf, was a contribution of some originality on the present condition, the antiquity, the inhabitants, and past history of this interesting group. Dr. Nansen's paper on Greenland was identical with that given to the Geographical Society, and already reported in NATURE.

The Report presented to this Section by Mr. Joseph Thomsor, on the geography and geology of the Atlas Mountains, can hardly be said to contain anything that has not already appeared in his narrative, except the lists of plants and of Coleoptera.

On the whole, it will be seen that the Geographical Section has not a very brilliant account to render.

\section{THE MECHANICAL PAPERS AT THE BRITISH ASSOCIATION.}

MONG the papers read in Section G, after the President had delivered his address, was one hy Mr. Alex. C. Humphreys, on water-gas in the United States. Water-gas is produced by the decomposition of steam by incandescent carbon. The two ways of effecting the decomposition, the intermittent and continuous, were described. In the first a cupola furnace is used : a blast of air raises the fuel to the necessary temperature; when this is effected the air is cut off and steam turned on, the blowing in of air and steam occurring intermittently. In the continuous process, steam is passed uninterruptedly through retorts containing carbon, which are heated externally, or steam and air are forced in continuously through a cupola furnace; but the latter proces: has the disadvantage of the resultant gases containing nitrogen. Water-gas has no light-giving properties so that it has to be carburized for illuminating purposes, or employed to raise some solid substance to a white heat. The different processes in vogue were described, and their theory explained. In conclusion the author gave expression to the belief that the day of gas, fuelgas, was rapidly approaching ; that even the great rival of gas, the electric light, may yet be dependent on it for the cheapest means of producing the electric current. Then will the gas engineer and the electrical engineer, shoulder to shoulder, be striving to correct the present wasteful strains on Nature's storehouses.

Precautions to be adopted when the electric light is supplied by means of transformers, by Mr. Killingworth Hedges. In a paper the author read at the Southport meeting of the British Association, he urged the necessity of regulations, and the adoption of proper safety appliances, in connection with electric lighting. In this paper he refers to the danger incurred when currents of high tension are converted into pressures suitable for incandescent lamps by means of transformers. The precaution necessary in such cases is either to earth the secondary circuit-which, however, has certain disadvantages-or to connect one or both of the leads to a safety appliance, which would automatically divert any excess current to earth, and at the same time shut off the supply in that portion of the faulty circuit by the fusion of the lead wire or mica-foils in the main cut-outs. Numerous experiments have been made with a vacuum protector, designed by the author, to ascertain the distance which an alternating current of high E.M.F. will leap across the two electrodes, which were fixed in the opposite ends of a glass tube from which the air had been partially excluded. The results differ from those observed by De la Rue with continuous currents ; the following phenomenon was noticed-that the arc, after starting between the two points, almost invariably extended itself to a bow-shape and ran back to the base of one or both of the platinum electrodes, one of which nearly always fused, leaving the other intact.

Electric launches on the Thames, by Prof. G. Forbes, F.R.S. Launches are chiefly wanted in the summer; to prevent injuries to banks the speeds should not be high, so that a comparatively small supply of accumulators is required. The author experimented with the Delta, 33 feet long, 6 feet beam, fitted with forty-four cells, weighing 2520 pounds. She is steered by a wheel in front within reach of three handles required to work her. The first is to put the current on or off; the second for half or full speed, and the third for going ahead or astern. The first is mechanically locked with the others, so that they cannot be moved without first cutting off the current. Fusible cut-outs are inserted to prevent injury to the motor if the propeller becomes jammed. The batteries are under the seats on each side of the boat, thus leaving clear space for passengers, of which she could carry twenty. The pull at full speed gives I 44 horsepower, or 1074 watts, including electrical losses, slip, and all friction. The average pressure at the motor terminals during the run was 78 volts, and the average current 23 amperes, which gives 1794 watts expended. This gives a total efficiency of 60 per cent. The author suggested that negotiations should be opened with the Thames Conservancy to establish charging stations, as there was likely to be a great demand in the future for electric launches.

Series electrical traction (Northfleet Tramways), by Mr. Edward Manville, M.Inst.C.E. The economical distribution of electrical power over long distances involves the use of a current of high potential, and by running the motors in series the advantages of high potential are secured. The main features of a series electrical tramway are a dynamo producing a current 